\title{
Political decentralization and local public services performance in Indonesia
}

\author{
Sujarwoto Sujarwoto \\ Institute for Social Change, University of Manchester, UK \\ Department of Public Administration, Brawijaya University, Indonesia
}

Received: July 02, 2012 Accepted: July 28, 2012 DOI: 10.5296/jpag.v2i3.2156

\begin{abstract}
This study contributes to the existing decentralization literature by examining the association between political decentralization and local public service performance in the context of decentralization reform in Indonesia. The hypothesis is that improve local public service performance within political decentralization is associated with effective local political institutions and accountable local government. The hypothesis is tested using Indonesian Governance Decentralization Survey 2006 which consists of 8,320 households living in 120 local governments. Local government public service performance is measured by perceived improvement of three basic public services: basic education, health and general administration services. Multilevel analyses are applied to account for the nested structure of perceived public service performance within decentralized local government. The results show that effective local political institutions, better informed citizen and transparency, citizen political participation via community programs, and the presence of social group in community are significant for improving local public service performance. These results reveal after we control the model with household and local government socio-demographic determinants. The empirical findings suggest that improved local public services performance requires well functioning local political institutions, better informed citizens and transparent local government, and effective channels for political participation.
\end{abstract}

Keywords: political decentralization, local public service performance, Indonesia. 


\section{Introduction}

The debate on the merits of decentralization has always been the focal point of studies in politics, economics and public administration. The previous debate has focused on the provision of a greater variety of public goods that may result from decentralization (Rondinelli, 1982; Conyers, 1983). More recently, the debate has been emphasized on political economy issues of institutional process and accountability through political decentralization reforms (Rodriguez, 2003; Fung, 2003; Bardhan, 2006a; Bank, 2008; Fan, 2009). Political decentralization reforms substantially differ from prior pure administrative and fiscal decentralization in which they evoke more than a downward delegation of resources and authority to local government. This recent decentralization emphasizes the working of political accountability through local political institutions to pursue better local government and public service (Fung, 2003; Grindle, 2007; Bardhan, 2006a; Bank2008). Proponents of political decentralization argue that bringing citizens closer to government and allowing them to hold elected officials accountable are an important foundation to achieve better local government and public services (Grindle, 2007). When local government is brought closer those receiving services, beneficiaries of these services would become active in demanding quality. Because those responsible for quality of services are local governments, citizens will be more motivated to demand improvements if services decrease in quality. Moreover, civil servants will have incentives to orient their behavior toward good service provision because of the potential for public disruption and complaints from unsatisfied citizens.

Although political decentralization promises accountable local government and better quality of public services, practice suggested that this was not necessarily the case. Instead of a consistent pattern of more responsive local governments, researchers found wide variability across them in terms of democratic practice and local public service performance. Research discovered that the incentives structures of local institutions are not necessarily aligned with pressures to improve performance (Grindle, 2007). Indeed, some studies indicated that elected local governments were not necessarily motivated to perform any better than their central counterpart in prior decentralization (Treisman2000). In some cases, local governments may actually be more subject to capture by vested interests than national ones after decentralization (Bardhan, 2006b; Lessmann, 2010). Bardhan and Mookherjee $(2006 b, 164)$ explain some of the basic trade-offs involved in the delegation of decision making to local government: "decisions are made on the basis of better (local) information, but they are made by an agent whose incentives differ from those of the principal thus leading to a loss of control or an abuse of power". Using cross countries analyses, Treisman (2000) found that countries which have more tiers of government tend to have higher perceived corruption and less effective in providing public services. This finding is supported by other cross countries studies which shown that public services can suffer as a result of decentralization (Litvack, 1998; Lessmann, 2010).

The gap between theory and practice of decentralization reform in developing countries has been assessed by politics, economics, and public administration scholars during the last 
decades. However, most of the existing theoretical and empirical research on decentralization in this area dealt with the impact of intergovernmental administrative and fiscal relations on the performance of the governance system as a whole (Tabellini, 1992; deMello, 2001; Fisman, 2002). Insufficient emphasis has been paid to the varying patterns in the adjustment of local accountability systems to the new political institution setting created by political decentralization reform. For example, limited research is found on the transformation of accountability relationships and their impact upon local government performance and public service delivery. There are some empirical studies which explore the relationship between political decentralization and local public service performance in developing countries. However, most of them either use countries or provinces as unit of analyses (Crook, 1998; Goldsmith, 1999; Fisman, 2002; Gong, 2006; Treisman, 2000; Blanchard, 2000; Bardhan, 2006a).

Whilst cross country study provides a large sample of countries and a relatively long time span, such studies are increasingly open to the criticism. There are important unobserved heterogeneities such as the difference of cultures and overall institutional setting between countries which may affect on local political accountability and public service performance. These unobserved heterogeneities may lead to bias estimates on the relation between political accountability and local public service performance (Maddala, 1999; Nabeshima, 2003; Kruse, 2009). Nabeshima (2003) notes that production functions that transform various inputs in public service provision into outputs may differ substantially across countries complicating estimation and interpretation. Moreover, the locus of decentralization reform in many countries is generally located at local government or district administration below provincial administration. Using provincial administration as a unit of analysis is less relevant for national policy since such analyses are unable to capture the dynamics of decentralization reform within districts or local governments in which decentralization is implemented.

This study contributes existing research on political decentralization and public service performance by analyzing local governments within a single country and by ascertaining the effect of local government contexts using multilevel analyses. The decision to use multilevel analyses and local governments as a unit of analyses provides some benefits. First, multilevel analyses offer the advantage of taking account of the nested structure of decentralization reform at local governments. These analyses allow us to investigate whether the effect of local government characteristics on local public service performance varies among local governments. Hence, the effect of local political accountability on local government performance can be tested appropriately using these analyses. Previous studies have examined associations of political decentralization and local government performance in Indonesia (Kaiser, 2006; Eckardt, 2008; Pattinasarany, 2009), but those studies do not account for nested structure of decentralization reform and local government performance. Second, the decision to use local governments in one country as a unit analysis was driven by the ability to control for a number of determinants that potentially intrude with the effects of political accountability on local government performance. Prior cross country studies show that accountability is embedded in the broader political, institutional, economic and social context of a country (Rondinelli, 1989; Litvack, 1998; Manor, 1999). Local government 
studies have the advantage since such contexts are considerably more similar within the boundaries of a single country than they are across countries. Hence, the effect of political decentralization on public service performance may more salient than when we use cross country to test the hypothesis. In addition, by using a large number of local governments within a single country this study is able to assess to what extent findings from the vast literature based on cross countries in this field are also found in a single country.

Indonesia constitutes a particularly interesting case not only because of the size of the country and its political and economic importance, but also the country has made remarkable progress in creating a decentralized system of government. The local government political system in Indonesia has changed from highly centralized government to decentralized government. This decentralization has devolved resources and responsibilities from the central government to local governments in all governments' administrative sectors, except for security and defense, foreign policy, monetary and fiscal matters, justice, and religious affairs. Significant public expenditures have also been devolved to all districts amounting to around $30 \%$ of total national expenditure. The decentralization has also prompted a major reorganization of political accountability chains in this country. First, it eliminates the hierarchical relationship between the central, provincial, and local governments. Citizens have freedom to elect their local leaders and parliaments through direct election. The major and district government officials are elected by and responsible to the locally elected assembly (Dewan Perwakilan Rakyat Daerah). Second, for locally assigned responsibilities, the branches of ministries in the districts are placed under the jurisdiction of local governments. Indonesia's decentralization, therefore, neatly reflects the concept of political decentralization.

In sum, the research questions to be answered in this paper are: (1) When local governments are charged with new responsibilities and are equipped with more resources, to what extent they can enhance their public service performance? Why are some local governments more effective than others in delivering public services?; (2) What role do political institutions and incentives play in shaping local public service performance? What is the implication of political decentralization for better local public services?

\section{Political decentralization and local public service performance}

The functioning of democratic local governments through decentralization has long merited attention in politics, economics, and public administration studies. Political decentralization means the devolution of political authority, responsibilities and public resources to local governments (Rondinelli, 1982; Conyers1983). This recent decentralization has widely believed as an effective remedy to reform local government in developing countries. As Andrews and Shah (2003) point out that local governments in many developing countries are becoming numerous and are increasingly required to play large roles in providing services, alleviating poverty, and facilitating development. Decentralization was vital for improving local government performance and citizen well-being in these countries. 


\section{Mll Macrothink}

Journal of Public Administration and Governance

ISSN 2161-7104

2012, Vol. 2, No. 3

The existing literatures in politics, economics and public administration offer some strong arguments in favor of decentralization policies. Most importantly, decentralization should enhance responsiveness, effectiveness and efficiency of local public services. In this perspective, decentralization is seen as a way to overcome informational constraints and align incentives in a political system. First, the empowerment of local governments is supposed to bring authorities closer to citizens and to increase accountability and the responsiveness of public services to local citizens' demands and needs (Oates, 1993). Second, decentralization is assumed to enhance competition among jurisdictions, which compete through tax policies, expenditure, public services and regulatory policies for mobile firms and individuals. Competition among local governments creates 'market-like incentives' for local governments to provide attractive combination of public services and policies at competitive local tax rates (Tiebout, 1956). Third, in addition to economic benefits, decentralization is also motivated by generally political objectives. Fuhr (1999) argued that the recent wave of political decentralization starting in the 1980 s can be seen as a response to the declining political legitimacy of centralistic government and fiscal policies. Increasing the public sector's political accountability is therefore preferred as the political agenda in many areas where decentralization policies are pursued today.

While there is an array of theoretical reasons why decentralization should be expected to improve local government performance, the empirical evidence across decentralized developing countries have not been as supportive. Variation on outcomes of decentralization is found across decentralized developing countries. Litvack, Ahmad, and Bird (1998) present evidence from Eastern and Central Europe and suggest that public services can suffer as a result of decentralization. Crook and Sverrisson (1999) have also provided evidence that despite extensive strides of devolution of authority and resources to democratically elected local governments, decentralization in Colombia, West Bengal and Brazil has achieved little in improving service delivery. Focusing on local governments in urban areas of developing countries, Mitlin (2000) comes to the conclusion that most of local governments fail to meet many of their responsibilities to large sections of the population within their jurisdiction. Nevertheless, scholars also found the contrast portraits of decentralization outcomes. Heller (2001) shows how decentralization reforms at Kerala and Porto Alegre increase the scope of local participation and strengthen of local democratic institutions and planning capacity. Blair (2000) explores the extent to which local democracy promoted participation and accountability in several countries. Stoner-Weiss (1997) describe the contextual factors that explained why some regional governments in Russia performed better than others in the wake of decentralization. From such work, we are beginning to understand the divergence between the promise of decentralization and its empirical consequences.

Why local governments response differently to new opportunities provided by political decentralization? A number of studies suggest that the existence of local political institutions fostering local accountability, the management of local government officials' political incentives, and the extent of mobilized local citizens' demand for accountability are necessary preconditions for effective political decentralization. 


\section{Mll Macrothink}

Journal of Public Administration and Governance

ISSN 2161-7104

2012, Vol. 2, No. 3

First, a number of studies suggest that outcome of political decentralization reform crucially depends on the availability of local democratic institutions ensuring that the local citizens can exercise control over local government affairs. Without local democratic institutions, political accountability is incomplete (Prudhomme, 1995; Crook, 1998; Bardhan1999). If political accountability is incomplete, decentralization will create incentives for local vested interests to capture the local political process and divert public resources to match their own interests (Bardhan, 1999; Bardhan, 2000). Riker (1964) suggests that the most obvious political institution guaranteeing accountability is local elections. Subsequent authors point out the importance of competitive and contestable local elections as an institutional mechanism to counter local corruption and to ensure local accountability (Rondinelli, 1989; Manor, 1999). They argue that where local elections are competitive and opposition parties have real opportunities to win positions of authority, incumbents will be motivated to prove their competence in the management of public affairs. In contrast, within partisan political pressures, incumbents will accommodate local vested interests rather than the local citizens' needs. Ward and Rodriguez (1999) examine the impact of political competition on the management of city in Mexico. They found the positive effect of political competition to enhance better management of city in Mexico.

Second, some studies focus on the management of local government officials' political incentives as pre-requisite for effective decentralization. A number of studies have focused on accountability in the trade-off between centralized versus decentralized provision of public goods. Seabright (1996) argues that accountability is a priori higher at the local level, since citizens who are better informed about government performance can directly monitor and evaluate public managers. Besley and Burgess (2001) show how information flows and participation affect the government's decision to respond to citizens' needs or not. Testing their hypothesis on panel data from Indian states, they find supporting empirical evidence for their model. They suggest that both transparency and participation increase the political cost of not responding, thus creating incentives for the government to be more responsive. Transparency ensures that information is available that can be used to measure the authorities' performance and to guard against any possibility misuse of powers. Mass media can play a key role in enabling citizens to monitor the actions of incumbents by providing information regarding government activities (Besley, 2002). Some scholars have found a direct link between the transparency in public administration decision making and the performance of public services (Brinkerhoff, 2003; McGee, 2011). These studies suggest that public administrations that include explicit mechanisms for citizens to scrutinize the process, participants and the information involved in the public policy decisions are likely to be efficient custodians of public funds.

Third, another strain of literature explains that the extent to which local citizens are mobilized to participate and demand accountability determines decentralization outcomes. According to this literature, social groups in the local community exert pressure on public sector to provide better services or more opportunities for participating in policy processes. The most well-known is Putnam's analysis of Italy's local governments and the impact of such social groups and social capital (Putnam, 1993). Putnam posits that the degree to which devolution 
of authority lead to better local government is based on the level of social groups and the extent to which these groups are able to monitor and to hold local officials accountable. The impact of community participation and social groups on a broad array of democratic reforms and public services is supported in subsequent empirical research (Booth, 1998; Woolcock, 1998; Heller, 2001; Bowles, 2002). These studies suggest that such social community participation and social groups can demand for better local governance. Social groups can also provide models of how improvements can be made, participate in decision making and implementation activities, and take an active role in monitoring the performance of elected and administrative official.

Following previous studies, we formulate three hypotheses. First, according to incomplete accountability hypothesis we expect that ineffective local political institution for ensuring accountability will lead to lack of public service performance. Second, according to management of local government officials' political incentives hypothesis we expect that local governments transparency and the degree of informed citizen are positively associated to local public service performance. Third, based on the action of citizens and structure of society hypothesis we expect that citizen political participation and the existed various social groups in local governments will lead to better local public service performance. Whereas some of these hypotheses have been tested and supported in earlier cross countries research, this study will test those hypotheses using local governments as a unit analysis.

\section{Indonesian decentralization experience}

Indonesia's decentralization meant a significant increase in the importance of autonomous local governments in service delivery. The failure of earlier attempts to decentralise, combined with the political crisis in 1998, became fertile for a far reaching approach to decentralization. Since the 1999, decentralization new bills were enacted and implemented in 2001. The enactment of these bills has changed Indonesia from a highly centralized state to a decentralized state. In particular the bill on regional government prompted a major reorganization of political accountability chains in this country. This bill eliminates the hierarchical relationship between the central, provincial, and local government. In a break from the past, the local government officials are elected by and responsible to the locally elected assembly. In addition, for locally assigned responsibilities, the branches of ministries in the districts are placed under the jurisdiction of local governments. With these new responsibilities, local governments are obliged to perform a set of key functions, including the provision of health, education, environmental and infrastructure services.

The concerns around ineffectiveness of indirect political accountability triggered to local government electoral reform toward direct elections (Pilkada Langsung) in 2004 (Erb and Sulistiyanto, 2009). This reform made the mayors more directly accountable to the local citizens by stipulating that he or she would be directly elected by citizens, and provided a clearer definition of the head's political functioning. The law stipulated that the mayors should: (1) administer the jurisdiction (daerah) as per the guidelines laid down by local parliament, (2) implement local laws, including budget, (3) present accountability reports to 
the local parliament and central government, and (4) provide information to citizens on the government's performance. The local parliaments or (Dewan Perwakilan Rakyat Daerah) had greater control over local government heads which previously under central government controlled through the Ministry of Home Affairs. In the new bills, local parliaments had the right to impeach local heads, thereby prematurely ending their terms upon an unsatisfactory delivery of an annual accountability speech.

It was believed that this democratic reform would make the district heads more accountable to their constituencies (Kaiser et al., 2005). Based on the new local government election amendment, the government decided to conduct the first batch of direct elections in June 2005 in the local governments where the parliament heads were ending tenure. The first batch of direct elections concerned all the mayors' positions that had come due between December 2004 and April 2005. More than a half of mayors were elected trough direct election until 2006 (Figure 1). The rest of mayors were still produced from prior autocratic regime election. All districts had been subject to direct elections by the end of 2009.

Figure 1: Mayor direct election in Indonesia from 2005 to 2007

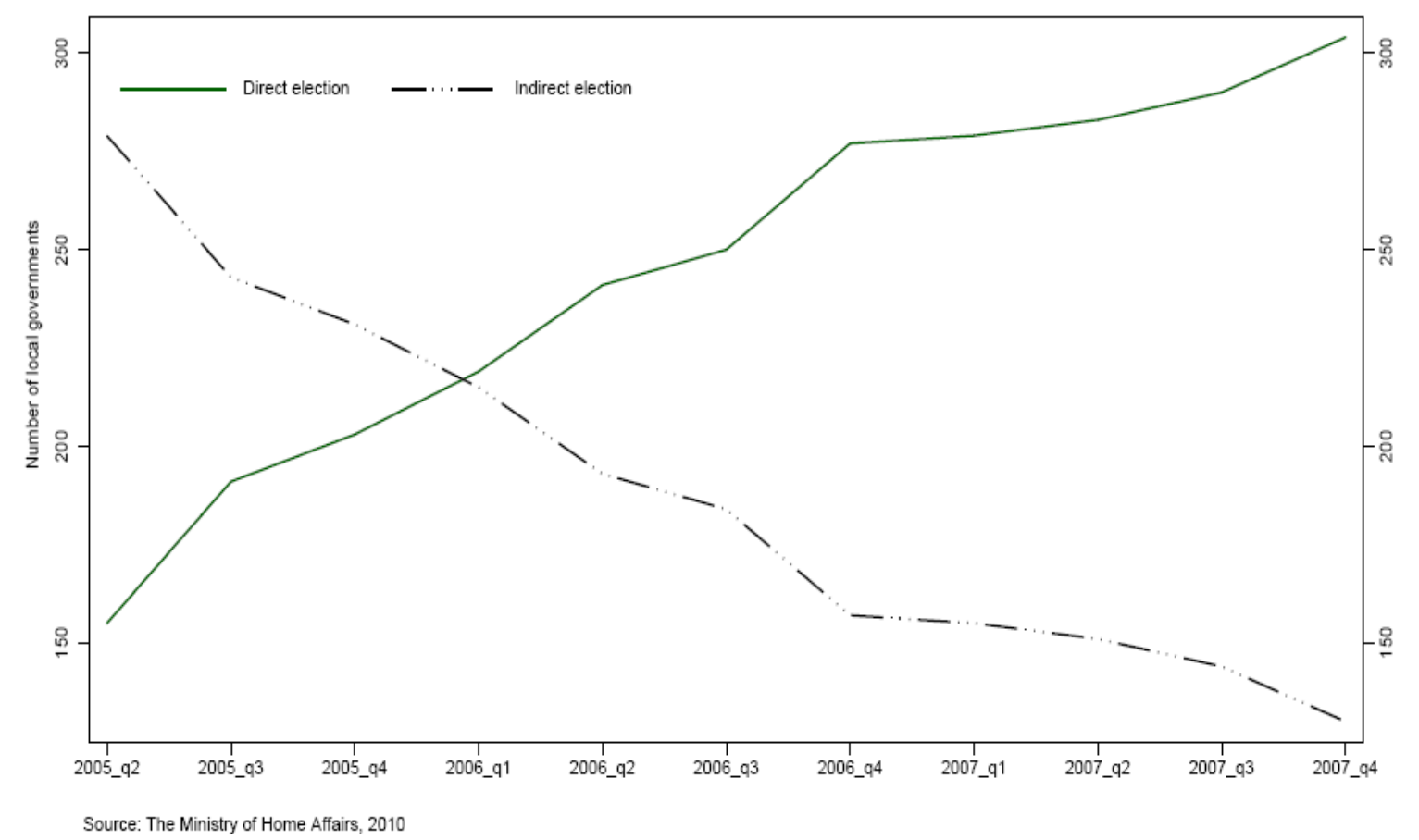

Decentralization in Indonesia also brings substantial resources to local governments. Decentralization has transferred more than a third of national budget to local governments. Figure 2 shows trend of central government transfer to local government since 1994. Fiscal transfer from central government to local governments is more than double compared to central government spending. The central government and donors also have continuously increased the pool of resources transferred to local governments in relative and absolute terms. This fiscal reform is followed by reassigning more than 2.5 millions of civil servants 
to districts. This human resources transfer makes the local governments have authority to manage human resources and capacity. With these changes, local governments are more independent in mobilizing resources, promoting their own interests, and initiating their own policies.

Figure 2: Trend of central government spending and local government transfer in Indonesia 1994 to 2007

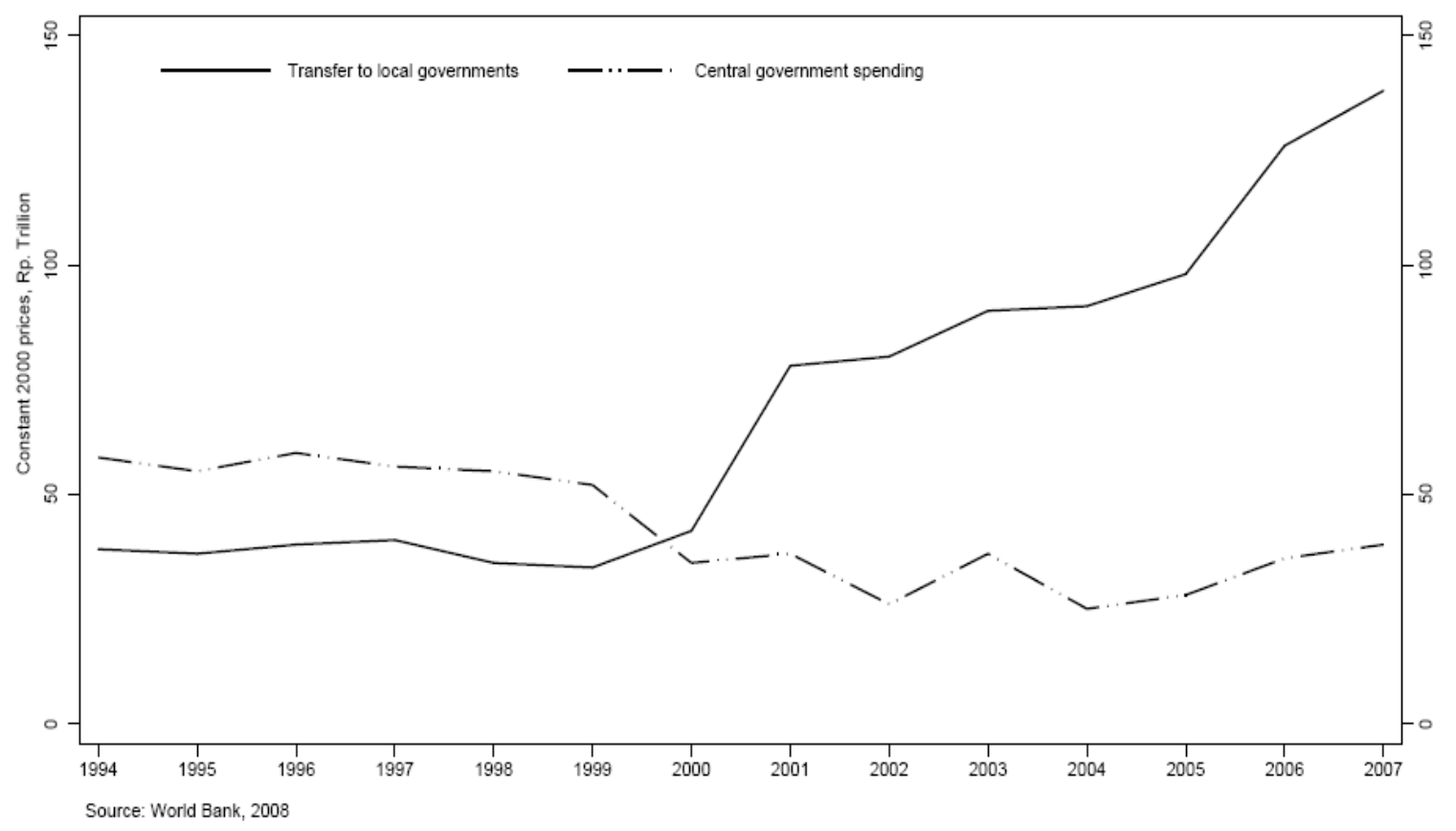

After five years decentralization, local governments' performance increasingly varies depending on the extent to which they took advantage offered by decentralization. World Bank (2003) found a significant number of local governments have forged ahead with reforms and became the locus for innovative form of government and better public services. Elsewhere, however, local political contexts became charged with lack of accountability and failure to respond to local needs (Asia, 2002). There are some evidences that suggest key political accountability mechanisms are only weakly developed in some of the newly empowered local governments (Kaiser, 2003; Malley, 2003; Bank, 2003a). Local parliaments were tending to over-reach their powers, blurring an effective balance of governance between executive and legislative agencies. Local politics centered on local parliaments were seen as becoming increasingly vulnerable to money politics. Local corruption and suspected bribes in the local government have occurred in several local governments (Bank, 2003a). These suggest that decentralization in the country does not have a uniform impact on local government's capacity but rather lead to a differentiation process with regard to both performance and level of accountability across localities. Hence, this study aims to understand how these different outcomes are brought about and to what extent the new incentives on political structure and resources from decentralization reform is associated with local public service performance. 


\section{Data, measurements and analytic strategy}

\subsection{Governance decentralization survey (GDS) 2006 and official statistics}

The hypotheses are tested using the data from the Indonesian Governance Decentralization Survey (GDS) 2006. GDS 2006 were fielded by the World Bank Indonesia in conjunction with the Centre of Public and Policy at Gadjah Mada University during 2006 (five years after a radical decentralization). Previous studies used this data to examine decentralization public services in Indonesia (Kaiser, 2006; Eckardt, 2008; Pattinasarany, 2009). GDS 2006 consists of a randomized sample of 134 local governments. The sampling ensured representativeness at both national and local government levels. In each of the sample districts, about 90 households were questioned using structured questionnaires containing their perceptions of various issues relevant to local governance and public service performance. In particular, the questionnaire included perceptions on the quality of public services, the workings of various political process, transparency, and participation. In this paper, we restricted only to respondents who already have political right to vote in Indonesian national election (age 17 years or older). This yields a sample of 12,860 households living in 134 local governments. Due to missing data on perceived performance, the total number of sample used for analysis becomes 8,320 households living in 120 local governments.

The GDS 2006 survey also collects information from public managers such as public school head, public hospital head, public health centre head, and local public education and health bureau head. More than 3000 public managers were asked about their education background and the implementation of decentralization in their institutions. We used the education backgrounds of public managers as a proxy to measure local government bureaucracy capacity.

The GDS 2006 survey was linked to other survey and independent official statistics dataset. First, we linked the survey with the socio-economic data from the Indonesian village potential census (Podes) 2006. The Podes dataset consists of detailed information about the number of active social groups in all village and urban neighborhoods within local governments. Aggregate villages and urban neighborhoods are calculated to measure the distribution of active social groups within a local government. Second, we linked the survey with the Indonesian socio economic survey (Susenas) 2006 from the governments Central Bureau of Statistics (Biro Pusat Statistik) to collect information on the distribution of adult literacy across local governments. Third, we linked the survey with the national election results 2004 to collect information on the distribution of political parties' faction in local governments and the proportion of national election voters at local governments. The data base consists of information about local governments which already implemented direct election up to 2007. We found more than a half of local governments elect mayors and parliaments through direct election in 2006. Other local governments are still led by mayors and parliaments resulted from previous regimes as they have started their jobs before direct election was implemented. This unique political condition provides opportunity to examine the effect of different local government political system on happiness. Lastly, we included 
district fiscal data from the Indonesian Ministry of Finance into the dataset. The Indonesian Ministry of Finance has compiled districts development budget and expenditure information since 1994. We use fiscal data 2005 (one year before the GDS survey) as districts development spending in the Indonesian government budgeting system takes at least one year to take effect. Since the price level of consumer goods and services in Indonesia vary across regions (Strauss, 2004), we deflate the amount of local governments' spending with consumer price index for urban and rural regions. Following Thomas and Frankenberg (2007) and Resosudharmo and Jotzo (2009), rural inflation is about 5\% higher than urban inflation. This calculation produces real spending adjusted with regional inflation. The consumer prices index 2005 data are retrieved from the Indonesian Government Central Bureau of Statistics (BPS).

This link with other survey and official statistics dataset enhances accuracy or reduces measurement error. The use of independent, official statistic dataset also alleviates concerns arising from the use of the same surveys in calculating both aggregate and individual determinants in the estimation (Deaton, 2001).

\subsection{Measurements}

This study uses citizens' responses of public service improvement as a proxy to measure local public service performance. Prior studies show that this measure is correlated with objective measure of performance and often used in business and public administration literature as a relatively easy and effective measures for evaluating service performance (see among others (Brown, 1983; Parks, 1984; DeHoog, 1990; Erevelles, 1992; Bennet, 1999; Swindell, 2000, Deichmann, 2003; Andrews, 2003; Myburgh, 2005; Bratton, 2007;Andaleeb, 2007)). Such subjective measure has also increasingly used in wellbeing and health literature as an alternative measure of wellbeing and health (Frey, 2002; Lane, 2000; Graham, 2009; Oswald, 2011).

The study focuses on changes in three particular areas where the local government provides front end services that are directly consumed by citizens: public health, public education, and general public services including the issuance of permits, identity cards and various licenses. These service areas were chosen since they represent the bulk of local public expenditure. Taken together, they account for between $40 \backslash \%$ and $50 \backslash \%$ of local public expenditure. These services are also crucial to human development and they allow for a representative and plausible appraisal of government performance. In the survey, respondents are asked "in your opinion, how is the quality of (services) in the districts, compared to two years ago (the beginning of decentralization)?" The services include school, local public health service, general public services, water management, and cleaning services. Perceived local public service performance index is calculated using confirmatory factor analysis for three types of services: public health services, public education services, and general public services. When the observed determinants are categorical, confirmatory factor analysis is also referred to as item response theory (IRT) analyses (du Toit, 2003; Baker \& Kim, 2004 cited from Muthen and Muthen, 2010). 
Consistent with the general hypothesis, we include a number of determinants into the analyses that measure variation in the effectiveness of local political institutions. Dummy direct local election is used to capture direct democracy as a mean for creating electoral accountability. To measure the effectiveness of local election, we use local conflict incidence related to local and national election. Perceived local corruption is used to measure interest group capture in local governments. Since the higher local conflict and interest group capture weaken accountability, we expect that the higher local conflict incidences and perceived corruption are negatively associated with performance. To capture the nature of political competition across local governments, we use the political party fragmentation of the local council based on the outcomes of the 2004 legislative election. If the share votes of the winner party is below 40\\% this means that the composition of political parties in given local government is more fragmented ${ }^{1}$. The direction of the causal effect is difficult to predict since higher party fragmentation could result in stiffer competition (positive effect) or paralysis and dispersion of accountability (negative effect).

The degree of informed citizen is measured by the proportion of adult literacy within local government and respondents' access to mass media, such as newspapers, radio, television, and Internet. Local government transparency is measured by the extent local government disseminates their development budget to public. Since informed citizen and transparency are often assumed will reduce the information problems related to government activities. In turn, both create forceful incentives for elected officials and civil servants to reduce opportunistic behavior. We therefore expect that the better informed local citizen and local government transparency are positively associated with local public service performance.

Citizen political participation is measured by three determinants. First, respondents' participation in local election is used to measure formal citizen political participation. Second, informal citizen political participation is measured by respondents' participation in communities programs, such as community labors, community health services, and water management. Third, the proportion of various social groups in local governments is used to measure the association between the density of active social groups and local public service performance. Since greater citizen political participation in the local government affairs and the density of active social groups should increase political accountability, the relationship between these determinants to local public service performance should be positive.

A number of determinants capturing fiscal and local bureaucracy conditions are included to measure the effect of fiscal decentralization and local bureaucracy capacity on local public services performance. The model controls for share of public spending on government administration, education and health on total expenditure. The proportion of public managers with graduate education is included to control whether bureaucracy capacity affects service performance. Mayors or bupati from new political party are included to control whether new local leadership matters for performance. In addition, to control bias on perceived performance we include individual and household socio demographic and geographic

\footnotetext{
${ }^{1}$ Based on the 2004 legislative election we found the highest share votes for the winner party is $40-50 \%$. The share votes for second and third winner parties are below $25 \%$.
} 


\section{Macrothink}

determinants. These individual and household socio demographic determinants include age, gender, education, unemployment and household expenditure. We create dummy determinants representing respondents living in remote island and Eastern part Indonesia to capture the effect of geographic location and regional development on local government performance. This geographic determinant is essential since development stages in Indonesia vary across regions (Lanjouw, 2001). Respondents living in mainland area and Western part as more developed region are used as reference groups. Table 1 presents summary statistics of analytic sample.

Table 1: The description of analytic samples

\begin{tabular}{lrrrr}
\hline & Mean & s.d. & min & max \\
\hline Health services & 1.71 & 0.52 & 0 & 2 \\
Education services & 1.71 & 0.68 & 0 & 2 \\
General administration services & 1.54 & 0.66 & 0 & 2 \\
Household & & & & \\
Age of household head & 45 & 13.14 & 18 & 90 \\
Female household head & 0.08 & 0.27 & 0 & 1 \\
Household head education & junior high school & 1.26 & no schooling & post graduate \\
Log household expenditure & 18.16 & 0.82 & 12.54 & 22.24 \\
Unemployed household head & 0.08 & 0.28 & 0 & 1 \\
Eastern part Indonesia & 0.44 & 0.50 & 0 & 1 \\
Remote islands & 0.04 & 0.20 & 0 & 1 \\
Participation in community programmes & 0.50 & 0.50 & 0 & 1 \\
Knowledge about village budget & 0.17 & 0.38 & 0 & 1 \\
Perceived corruption & 0.29 & 0.45 & 0 & 1 \\
Knowledge conflict related & 0.09 & 0.28 & 0 & 1 \\
local and national election & & & & 1 \\
Participate in local election & 0.47 & 0.50 & 0 & 1 \\
Have access to newspaper, & 0.84 & 0.36 & 0 & \\
radio,tv,and Internet & & & & \\
Local governments & & & & \\
Proportion of adult literacy & 0.90 & 0.06 & 0.55 & 0.98 \\
Proportion of active social groups & 0.26 & 0.18 & 0 & 0.80 \\
Political fragmentation & 0.81 & 0.39 & 0 & 1 \\
Direct democracy & 0.60 & 0.49 & 0 & 0.98 \\
Share of public service spending & 0.88 & 0.05 & 0.74 & \\
on total development spending & & & & \\
Proportion public managers & 0.21 & 0.10 & 0.08 & \\
with graduate education & & & & \\
Mayor from new political party & 0.44 & 0.50 & & \\
N Households & 8,320 & & & \\
N Local governments & 120 & & & \\
\hline
\end{tabular}

\subsection{Multilevel multiple indicator multiple causes analyses}

The locus of political decentralization reform in this study is local government. In this regard, the analysis needs to recognize the nested structure of decentralization reforms and local public service performance at local governments. Multilevel analyses are appropriate for this 
analysis. Existing analyses in this area are based either on aggregate data (Eckardt2008) or at individual level (Bennet, 1999; Bratton, 2007; Pattinasarany, 2009) using ordinary regression analyses. Hence, such analyses ignore the nested structure of the data in which individuals are hierarchically clustered within local governments. Ignoring this nesting of individuals within large local government units may lead to the underestimation of standard errors of effects of local government level characteristics. As a result, in ordinary regression analyses the significance of local government level effects is overestimated. Multilevel regression analyses are able to account for this clustering of individuals within local governments by separating individual variance in perceive service performance from local government variance in perceive performance. Hence, hypotheses on effects of local governments characteristics can be tested appropriately using this technique. For detailed technical information on multilevel analyses we refer to Skrondal and Rabe-Hesketh (2008).

We use multilevel multiple indicator multiple causes since local public service performance is an unobserved or latent determinant of three basic services (i.e. health, education, and general administration services). The latent determinant of local government public services are tested using logistic item response theory models in which factors with ordered categorical indicators are referred to as Samejima's graded response model (Muthen, 2010). The Mplus package makes it possible to carry out the analysis through logistic item response theory model while other statistical packages (such as Lisrel and Amos) are usually used in factor analysis for continuous indicators. The models are specified households as level 1 units (i.e. the hierarchically lowest level of analysis), and local governments as level 2 units (the highest level) (Figure 3). The models include residual at the household and local government level. The residual variance is partitioned into between local government's components (the variance of local government residuals) and within local government (the variance of household level residuals). In this analysis, we performed multilevel multiple indicator multiple causes models for household and local government determinants. For each of our models, we report the estimated regression coefficient, standard errors, household and local government residual variance, Comparative Fix Index (CFI) and Root-Mean Square Error of Approximation (RMSEA) as an indicator of model fit (Steiger1990). The CFI falls strictly between the values of 0 and 1. A CFI value of 0.95 or bigger is often considered to indicate good fit though a modest value of 0.90 is also accepted in some cases (Hu1999). The RMSEA provides a test of the extent to which the target model as fitted to the sample data 'approximates' the population model. A RMSEA value of $<0.05$ is taken to indicate close fit (Browne, 1993; Hu, 1999), who recommended 0.06 as an upper boundary). Weighted least-square with mean and variance adjustment (wlsmv) estimator is used as Muthen et al. (1997) suggested that this is the optimal choice for categorical indicators. As Muthen explained, Mplus supports modelling with categorical observed variables or combination of both continuous and categorical outcomes. Further, it also provides a more flexible parameterization than conventional structural equation modelling software in terms of its categorical outcome modelling for multiple-group analysis using threshold measurement parameters that allow for partial invariance across time and group (Muthen, 1996). 
Figure 3: Research framework

Decentralisation:

(A) Political decentralisation (i.e. direct democracy)

(B) Fiscal decentralisation (i.e. fiscal transfer from central to local government, public spending on public services)

Local government characteristics:
(A) Leadership
(B) Political competition
(C) The density of active social group
(D) Bureaucrats education
(E) Proportion of adult literacy

Local government

\section{Individual}

Household characteristics:

(A) Socio demographic determinants (i.e. age, female, expenditure, employment)

(B) Participation in community programs.

(C) Participation in political election

(D) Perceived corruption at local government.

(E) Knowledge about village budget

(F) Knowledge about conflict related to local and national election.

(G) Have access to newspaper, radio, television, and internet.

(H) Living in remote islands and eastern Indonesia. 


\section{$\triangle$ Macrothink}

\section{Results}

A sense of the importance of the area association with local government performance can be gained from the maps. We map aggregate citizen response on local public service performance across local governments (Figure 4). The map highlights the geographical variations in local government performance across local governments. An attempt at a summary is given in table 2 (West-East correlation and mainland-remote islands correlation). The map and table hint at West-East gradients and mainland-remote islands gradients. For instance, simple correlations between population centroids and local public service index show that as one moves East, local government performance is reported to decrease (-0.073); likewise, as one moves remote islands, local public service index is also reported to decrease (-0.092). Disparities in public services performance exist between Western and Eastern as well as between mainland and remote island.

Figure 4: The distribution of services satisfaction across 120 local governments)

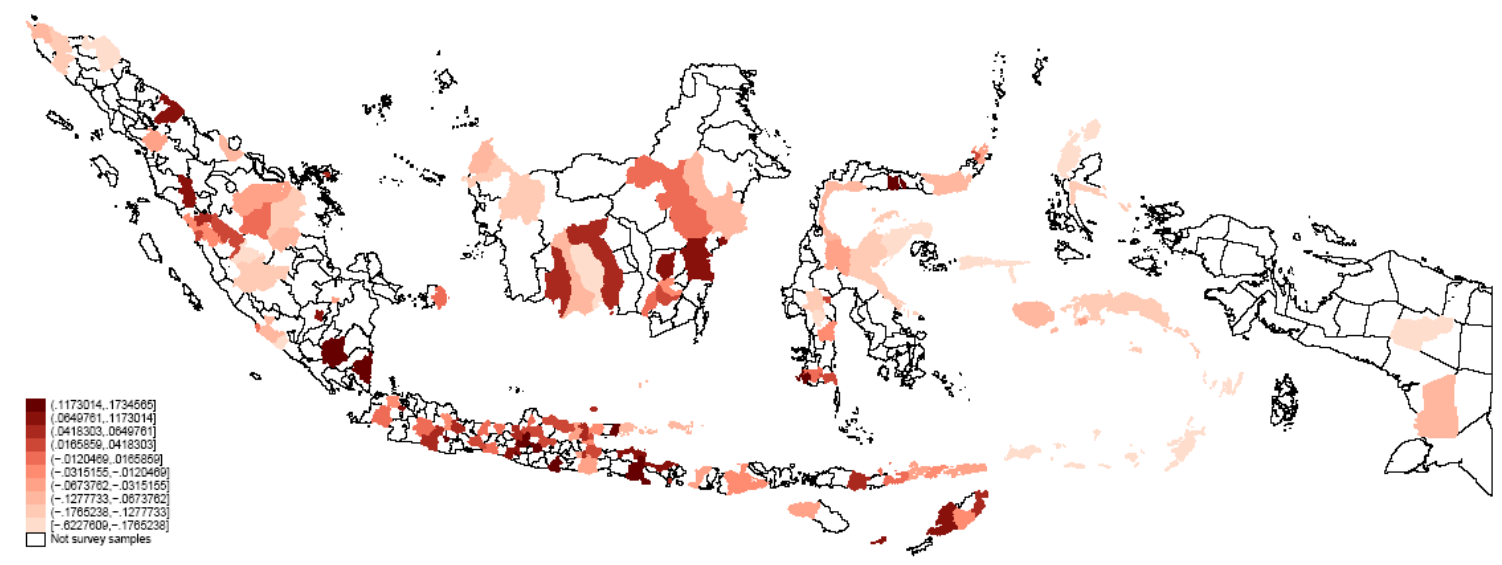

Table 2. Centroid correlation with service satisfaction index

\begin{tabular}{lrr}
\hline Population centroid & West-East & Mainland-Remote \\
\hline Service satisfaction index & $-0.073 \ddagger$ & $-0.092 \ddagger$ \\
\hline Significance: $\dagger: 5 \% \ddagger \leq 1 \%$ & &
\end{tabular}

Table 3 presents the five highest and lowest ranks of perceived local public services performance within major islands in Indonesia. The stark contrast is shown between four major islands (Java-Bali, Sumatra, Kalimantan, and Sulawesi) and Eastern and remote islands. While some local governments in four major islands reports better public service performance, most of local governments in Eastern and remote islands report lesser public service performance. 


\section{Al Macrothink}

Journal of Public Administration and Governance

ISSN 2161-7104

2012, Vol. 2, No. 3

Table 3: The distribution of five highest and lowest ranks of perceived local public service performances

\begin{tabular}{|c|c|c|c|}
\hline Local governments & 5 highest & Local governments & 5 lowest \\
\hline \multicolumn{4}{|l|}{ Sumatra } \\
\hline Kab. Way Kanan & 0.16 & Kab. Aceh Utara & -0.23 \\
\hline Kab. Lampung Timur & 0.14 & Kab. Aceh Timur & -0.21 \\
\hline Kab. Lampung Utara & 0.14 & Kab. Bungo & -0.18 \\
\hline Kota Prabumulih & 0.09 & Kab. Bengkulu Selatan & -0.18 \\
\hline Kab. Asahan & 0.09 & Kab. Pidie & -0.17 \\
\hline \multicolumn{4}{|l|}{ Java-Bali } \\
\hline Kab. Karanganyar & 0.17 & Kab. Sumenep & -0.07 \\
\hline Kota Tasikmalaya & 0.16 & Kab. Lamongan & -0.06 \\
\hline Kab. Trenggalek & 0.15 & Kab. Malang & -0.06 \\
\hline Kota Yogyakarta & 0.14 & Kota Cimahi & -0.02 \\
\hline Kab. Pamekasan & 0.14 & Kota Tangerang & -0.02 \\
\hline \multicolumn{4}{|l|}{ Kalimantan } \\
\hline Kota Balikpapan & 0.12 & Kab. Kotawaringin Timur & -0.22 \\
\hline Kab. Barito Timur & 0.09 & Kab. Sekadau & -0.18 \\
\hline Kab. Paser & 0.07 & Kab. Bengkayang & -0.17 \\
\hline Kab. Kotawaringin Barat & 0.06 & Kab. Sanggau & -0.14 \\
\hline Kab. Katingan & 0.05 & Kab. Sambas & -0.12 \\
\hline \multicolumn{4}{|l|}{ Sulawesi } \\
\hline Kab. Boalemo & 0.15 & Kab. Banggai & -0.22 \\
\hline Kab. Takalar & 0.13 & Kab. Enrekang & -0.18 \\
\hline Kota Palopo & 0.03 & Kab. Tana Toraja & -0.17 \\
\hline Kota Manado & 0.03 & Kab. Tojo Una Una & -0.16 \\
\hline Kab. Bulukumba & 0.03 & Kab. Morowali & -0.14 \\
\hline \multicolumn{4}{|l|}{ Eastern Indonesia } \\
\hline Kota Kupang & 0.07 & Kab. Jayawijaya & -0.62 \\
\hline Kab. Ngada & 0.05 & Kab. Kepulauan Sula & -0.42 \\
\hline Kab. Belu & 0.04 & Kab. Maluku Tenggara & -0.29 \\
\hline Kab. Sikka & -0.01 & Kab. Halmahera Utara & -0.25 \\
\hline Kab. Timor Tengah Selatan & -0.03 & Kab. Maluku Tengah & -0.25 \\
\hline \multicolumn{4}{|l|}{ Remote islands } \\
\hline Kab. Jayawijaya & -0.62 & Kab. Timor Tengah Selatan & -0.03 \\
\hline Kab. Kepulauan Sula & -0.42 & Kab. Alor & -0.04 \\
\hline Kab. Maluku Tenggara & -0.29 & Kab. Manokwari & -0.08 \\
\hline Kab. Halmahera Utara & -0.25 & Kab. Mappi & -0.09 \\
\hline Kab. Maluku Tengah & -0.25 & Kab. Buru & -0.13 \\
\hline
\end{tabular}

Do differences in local conditions for political accountability relate to differences in the performance of the local governments? Figure 5 presents simple bivariate correlation between selected local government determinants and perceived local public service performance index. 


\section{Mll Macrothink}

Figure 5: Correlation between local public service performance and some selected local government's determinants.
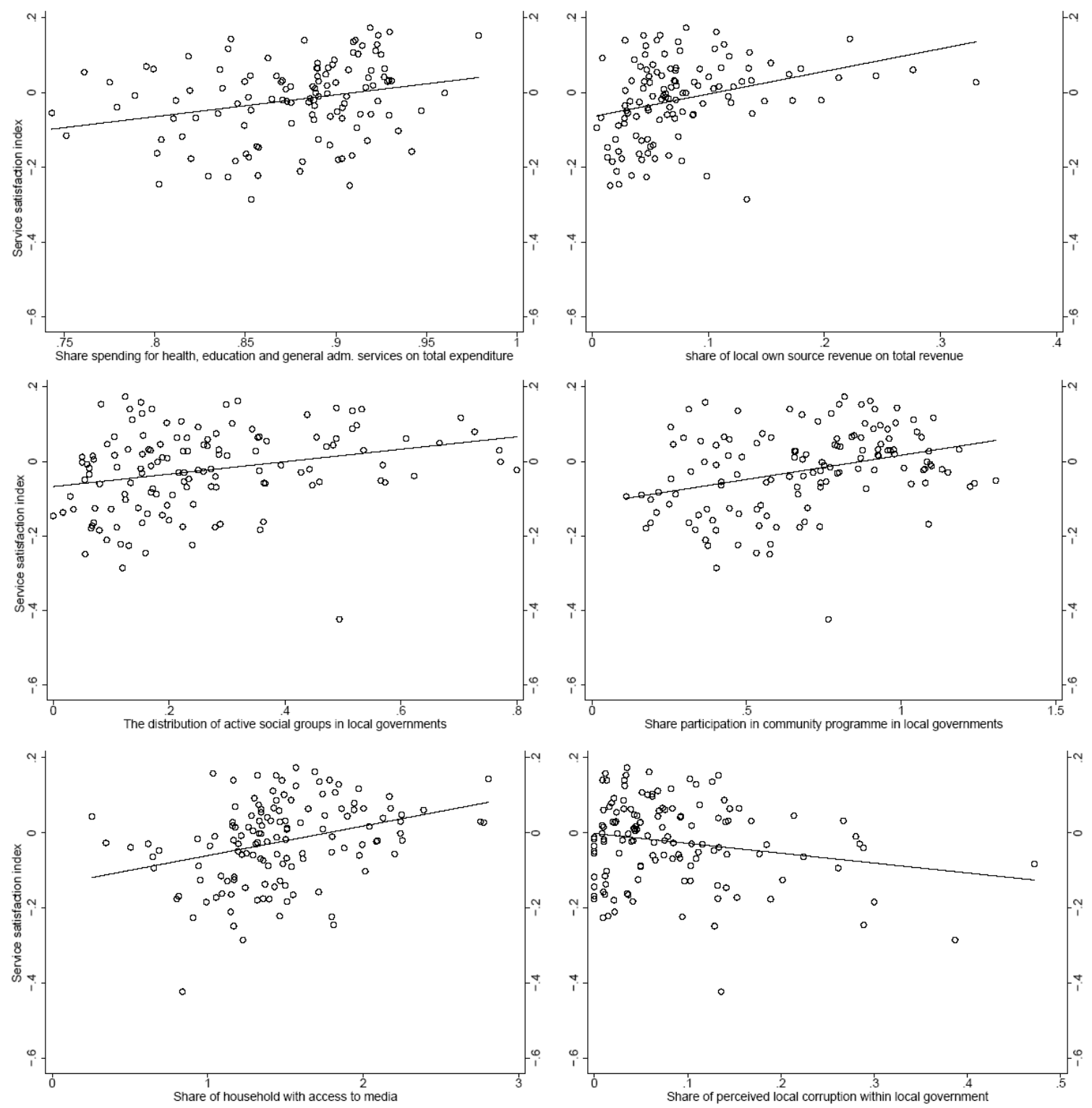

Some local government determinants are systematically associated with local public service performance. Local government fiscal capacity and local government spending on health, education and general administration services are positively correlated with performance. Likewise, the density of social groups, community participation and access to mass media are also positively correlated with performance. In contrast, perceived corruption has negative correlation with local public service performance. 


\section{Macrothink}

Table 4 presents regression results of multilevel regression analyses before and after local government control determinants are included in the model. Model A presents regression result before local government control determinants are included. All factors loading are significant in the individual level except for education services $(0.419, p<1 \%$ for health services, $0.035, p>10 \%$ for education services, and $0.732, p<1 \%$ for general administration services). The results for local government level shows all factors loaded are significant (0.792, $p<1 \%$ for health services, $0.257, p<10 \%$ for education services, and $0.848, p<1 \%$ for general administration services).

Most of main determinants appear to be significant on local public service performance. Local corruption and perceived conflict incidence on election are negatively associated with service improvement $(-0.266, p<1 \%,-0.031, p<10 \%$ respectively). Citizen participation in various community programs improves performance $(0.058, p<1 \%)$. Local government transparency as indicated by respondents' knowledge on public dissemination on development budget makes more likely better service outcomes $(0.076, p<1 \%)$. Informed citizen as measured by their access to mass media also significant for local public service performance $(0.050, p<5 \%)$. Likewise, the density of social groups matters for local public service performance $(0.396, p<1 \%)$. In contrast, political fragmentation is negatively associated with service performance $(-0.257, p<5 \%)$. Null findings are found for the rest of local government determinants. 
Table 4: Results of multilevel regression of local public service performance

\begin{tabular}{|c|c|c|c|c|}
\hline & \multicolumn{2}{|l|}{ Model A } & \multicolumn{2}{|l|}{ Model B } \\
\hline & coef. & (s.e) & coef. & (s.e.) \\
\hline \multicolumn{5}{|l|}{ Factor loading of observed local public services } \\
\hline \multicolumn{5}{|l|}{ Household } \\
\hline Health services & $0.419 \ddagger$ & 0.028 & $0.404 \ddagger$ & 0.032 \\
\hline Education services & 0.035 & 0.022 & $0.052 *$ & 0.027 \\
\hline General administration services & $0.732 \ddagger$ & 0.042 & $0.745 \ddagger$ & 0.052 \\
\hline \multicolumn{5}{|l|}{ Local government } \\
\hline Health services & $0.792 \ddagger$ & 0.109 & $1.000 \ddagger$ & 0.097 \\
\hline Education services & $0.257 \dagger$ & 0.117 & $0.372 \dagger$ & 0.133 \\
\hline General administration services & $0.848 \ddagger$ & 0.110 & $1.460 \ddagger$ & 0.093 \\
\hline \multicolumn{5}{|l|}{ Determinants } \\
\hline \multicolumn{5}{|l|}{ Household } \\
\hline Age of household head & $0.037 \dagger$ & 0.019 & $0.040 *$ & 0.021 \\
\hline Female household head & 0.026 & 0.017 & $0.031 *$ & 0.018 \\
\hline Household head education & 0.019 & 0.020 & 0.027 & 0.021 \\
\hline Household expenditure & 0.004 & 0.023 & 0.017 & 0.025 \\
\hline Unemployed household head & -0.022 & 0.019 & -0.026 & 0.022 \\
\hline Eastern part Indonesia & $-0.154 \ddagger$ & 0.046 & $-0.130 \dagger$ & 0.051 \\
\hline Remote islands & $-0.111 \dagger$ & 0.035 & -0.069 & 0.048 \\
\hline Participate in community programme & $0.058 \ddagger$ & 0.018 & $0.058 \ddagger$ & 0.020 \\
\hline Knowledge about village development budget & $0.076 \ddagger$ & 0.017 & $0.061 \ddagger$ & 0.018 \\
\hline Perceived corruption in local government & $-0.266 \ddagger$ & 0.019 & $-0.263 \ddagger$ & 0.021 \\
\hline Knowledge conflict related to local and national election & $-0.031 *$ & 0.016 & $-0.040 \dagger$ & 0.018 \\
\hline Participate in local election & -0.007 & 0.025 & 0.005 & 0.029 \\
\hline Have access to newspapers,radio,tv and Internet & $0.058 \ddagger$ & 0.021 & $0.055 \dagger$ & 0.022 \\
\hline \multicolumn{5}{|l|}{ Local government } \\
\hline Direct democracy & 0.170 & 0.114 & 0.055 & 0.139 \\
\hline Proportion of adult literacy & 0.014 & 0.121 & 0.253 & 0.135 \\
\hline Proportion of active social groups & $0.396 \ddagger$ & 0.124 & $0.497 \ddagger$ & 0.127 \\
\hline Political fragmentation & $-0.257 \dagger$ & 0.130 & $-0.149 *$ & 0.144 \\
\hline $\begin{array}{l}\text { Share of public services spending } \\
\text { on total development spending }\end{array}$ & & & 0.001 & 0.122 \\
\hline $\begin{array}{l}\text { Proportion of public managers with } \\
\text { graduate education }\end{array}$ & & & 0.042 & 0.130 \\
\hline Mayor from new political party & & & -0.004 & 0.141 \\
\hline $\begin{array}{l}\text { Residual variances at household and local government } \\
\text { Household }\end{array}$ & & & & \\
\hline Household & $0.881 \ddagger$ & 0.019 & $0.900 \ddagger$ & 0.021 \\
\hline Local government & $0.731 \dagger$ & 0.114 & $0.689 \dagger$ & 0.121 \\
\hline CFI & 0.939 & & 0.941 & \\
\hline RMSEA & 0.011 & & 0.010 & \\
\hline
\end{tabular}

Model B presents regression results after all control determinants are included in the model. The correlation between unobserved or latent local public service performance and all factors loading becomes all significant. The association of all main determinants on local public 
service performance remains similar. Controlling for individual and local government determinants, perceived corruption and conflict related to local and national election decrease service performance $(-0.263, p<1 \%$ and $-0.040, p<5 \%$ respectively $)$. Political fragmentation remains negatively associated with service performance $(-0.149, p<10 \%)$. This negative association may indicate that instead of stiffer political competition, party fragmentation results in paralysis and dispersion of accountability. Direct local democracy as a mean for enhancing electoral accountability is positively associated with performance, but the association appears not significant.

Respondents' knowledge on public dissemination on development budget remains positively associated with service performance $(0.061, p<1 \%)$. Better informed citizen as indicated by adult literacy and higher access of local citizens to various mass media are also positively associated with service performance. However, the significant association is only shown on access to mass media $(0.055, p<5 \%)$. Citizen participation in community programs increases perceived service performance $(0.058, p<1 \%)$, while participation in local election is not $(0.005, p>10 \%)$. The density of social groups remains significant for service performance $(0.497, p<1 \%)$. This finding indicates that households living in the higher density of social groups perceive better performance of services. In addition, null findings are shown on the association of public spending, local bureaucracy capacity and leadership on local public service performance.

Household control determinants show expected results. Older household head tends to perceive better performance. Female household head perceives better performance than male. Those living in Eastern part of Indonesia perceive less performance. Other individual socio demographic determinants are not significantly associated with perceived performance.

The local government variance is significant. This finding indicates that perceived public services performance varies between local governments. The estimation of variance at local government level goes some way to ensure that the rest of our estimates (from age to mayor come from new political party) are robust against unobserved local government heterogeneities. Furthermore, the two models display good model fit indicators with CFI >0.90, and RMSEA <0.049 (CFI for model $\mathrm{A}=0.939$ while for model $\mathrm{B}=0.941$, RMSEA for model $\mathrm{A}=0.011$, while for model $\mathrm{B}=0.010$ ).

\section{Discussion}

This study aims to examine whether transfer responsibilities and resources through decentralization reform associated with increase local public service performance. Local public service performance is measured by citizens' perception on three basic public services sectors: health, education and general administration services. Three hypotheses are proposed to answer research questions: incomplete accountability hypothesis, management of local government officials' political incentives hypothesis, and action of citizens and structure of society hypothesis. 
We improve a number of methodological steps in this analysis. First, we use local governments as a unit of analysis. This unit of analysis has advantages since such contexts are considerably more similar within the boundaries of a single country than they are cross countries. Hence, the effect of decentralization on public service performance may more salient when we use local government as a unit analysis rather than countries or provinces as unit of analysis. Second, while existing analyses use individual or aggregate data using ordinary linear regression we use multilevel analyses address the nested structure of decentralization reforms and public service performance in local government's context. Hence, using multilevel analyses and local government as a unit of analysis, we are able to control for unobserved heterogeneities between local governments that potentially intrude with the effect of political decentralization on local government performance. Third, we employ the multilevel multiple indicator multiple cause model to analyze the nested structure of local public service and unobserved local public service performance. The results of this study therefore may be more robust than prior single level studies which often use ordinary linear regression analyses and factor analyses.

The results confirm that ineffective local political institution for ensuring local political accountability lead to lack of public service performance. Local public service performance decreases along with the perception of local conflict on election, local corruption, and political fragmentation. Local direct democracy as a means for creating political accountability and leaders' circulation is also not associated with local public performance. Reflecting decentralization experiences across new decentralized developing countries, these results elicit that poorly performing local government is revealed when channels for ensuring political accountability are not available in local government level. In this case, political decentralization will increase local corruption rather than strengthen democracy and improve local public services (Prudhomme, 1995; Litvack, 1998; Crook, 1998; Goldsmith, 1999; Treisman, 2000; Fisman, 2002). While prior studies found this evidence across developing countries, our findings show that the negative association between ineffective local political institutions on local public service performance holds throughout local governments within a country.

Our results show that the degree of informed citizen and local governments' transparency are positively associated with local public service performance. This positive association may signal that in the lowest structure of government, citizens can better oversee the way local agencies use public fund and deliver services in daily life. Here, informed citizens and information dissemination can be understood as channels for improving citizens' political awareness. By providing information about how government spent their money, local citizens particularly who have more access to mass media will have opportunities to monitor and to evaluate local government activities. As Bestley et al. (2002) explain that mass media can play a key role in enabling citizens to monitor the actions of incumbents by producing and disseminating information related to government activities to citizens. This can lead to more accountable and responsive government to its citizens' needs. Whether or not we can attribute this effort as a causal chain, between participation and transparency to more accountable local governments and therefore improved services, can be contested. The results may also be 
driven by other factors. For instance, information dissemination might by itself change respondents' perceptions of services, simply by providing more information about changes and improvements in service delivery. The causation between these determinants is beyond the scope of this study, but an important future area of research.

The results confirm some parts of third hypothesis. We find that informal citizen political participation and the active social groups in local governments improve local public service performance. In contrast, formal citizen political participation in local election is not significantly associated with performance. These findings may indicate that within less effective local election, participation in community programs is likely more effective to articulate local citizen voices in policy making to improve performance. The effectiveness of community participation is also supported from positive association of social groups on performance. This study shows that respondents living in denser social groups perceive better performance than those living in less dense social groups.

There is a well established literature on the benefits of individual and community social capital on development outcomes. Getting citizens involved directly in various community programs can improve local governments' capacity in providing services. Community participation could affect this capacity by, for example, providing direct material benefits or helping to target material resources most efficiently within a community (Fox, 1996; Blair, 2000). Meanwhile, social groups not only can exert pressure on local government to provide better services, but also can provide models of what kind of services and how improvement can be made according to local concerns (Heller, 2001). In Indonesian contexts, the positive association of community participation and social groups for development is documented in previous studies (Shiffman, 2002; Grootaert, 2002; Sullivan, 1992; Bank, 2003). These studies show that the involvement of local community volunteers and various social organizations have become a hallmark of socioeconomic development in the country. In many instances these organizations began as grassroots initiatives and were subsequently adopted by higher level of government as regional and national programs (Shiffman, 2002; Bank, 2003). Hence, our results confirm that the benefits of individual and community social capital not only limited for improving outcomes of such community programs, but also for improving local public service performance.

We hope future research will be able to deal with some of limitation on this study. Although previous studies show that citizens' responses can be used to measure local government performance, survey responses of citizens may suffer from social desirability bias. For instance, respondents may be responding in a polite manner to survey questions about satisfaction, but not in away that necessarily represent their real views. Respondents may also have low expectations about service delivery, which when compared to actual quality of service lead to relatively high levels of satisfaction. Moreover, perceived measured is often affected by determinants unrelated to decentralization performance such as age, gender, education, income, ethnicity, attitudes and predispositions related to political beliefs or past experiences. We control this bias by including socio-demographic determinants in the models. Nevertheless, these issues may still affect the findings. Future anticipated data collection and 
analysis will need to improve measurement for individual localities and provide more rigorous controls for potential biases on individual satisfaction as a measure of public service delivery quality, including peer group/expectations effects, as well as actual associations with objective measures. Furthermore, rather than threat different accountability mechanism as equally effective given prevailing local service delivery conditions, we suggest that different accountability mechanism (e.g. bottom-up versus top-down or information/participation versus sanctions-based mechanism) may be more effective in particular contexts. Increased evidence on the general, as well as location-specific efficacy of different accountability mechanisms for public service delivery represents a critical input into the on-going policy debate about decentralization and service in Indonesia.

While the interpretation of the results should be viewed in light of certain limitations, our findings have important implications both for the literature and practice of decentralization and development in developing countries. First, our research show that local government continued to vary in terms of their service performance and in terms of the extent to which they took advantage of the opportunities offered by decentralization. While most of prior studies show that this variation is shown across developing countries or provinces within a country, this study find that this variation is revealed across local governments within a country. This finding implies that the call for examining at what scale or arena do researchers make comparisons. This study suggests that the consequence of decentralization reform on local government performance is more relevant if we use local governments as a unit of analysis.

Second, the benefits predicted by proponents of decentralization as consequences of decentralization provide a palette of possibilities, not of realities. Indeed, this study indicates that the promises of political decentralization are likely to be realized when channels for political accountability is existed in local governments. The empirical evidence shows that the likelihood of citizens are satisfied with public service delivery is associated with effectiveness of local political institutions, better informed citizen, transparent of local governments, and citizen political participation. These findings must surely constitute a conclusion of which local politicians and service providers might usefully take note.

\section{Conclusion}

The general hypothesis tested in this article is that the variation of local public service performance within decentralized local government is to significant extent determined by the effectiveness of local political institutions, better informed citizen and transparency, and citizen political participation. The results are broadly consistent with the predictions of the hypothesis. More effective local political institutions, better informed citizen and transparency, citizen political participation via community programs, and the presence of social groups in communities are all associated with higher performance. These effects remain statistically robust across all regression specifications. While we should be cautions in interpreting the results as causality in the strict sense, they still provide an interesting pattern that should be addressed in further empirical analysis. 


\section{I Macrothink}

Journal of Public Administration and Governance ISSN 2161-7104 2012, Vol. 2, No. 3

Poorly performing local public services are often deeply rooted in their political and social contexts. Local governments often fail to provide better public service when political accountability is absent due to weak checks and balances, lack of transparency, and weak electoral incentives. If political accountability is incomplete, decentralization will create powerful incentives for political and bureaucrat agent to capture local political process and misallocate public resources. Conversely, better performing local public services are consistently with higher citizens' political participation and active social groups within community which strengthen local government to be responsive and deliver efficient services. Higher accountability will increase the political costs of inefficient and inadequate public decisions and, thus, public service performance is likely to improve. This requires a politically active community that is able to participate in examining accountability.

\section{References}

Andaleeb, S., Siddiqui, N., and Khandakar, S. (2007). Patient satisfaction with health services in Bangladesh. Health Policy and Planning, 22(1):263-273.

Andrews, M. and Shah, A. (2003). Assessing local government performance in developing countries. In Shah, A., editor, Bringing civility in governance: Handbook on public sector performance reviews. Washington DC: World Bank.

Asia Foundation (2002). First Indonesian rapid decentralization appraisal - synopsis of findings. Washington DC: Asia Foundation.

Baiocchi, G. (2006). Decentralization, corruption, and government accountability. In Rose-Ackerman, S., editor, International handbook on the economic of corruption. Cheltenham:Edward Elgar Publising.

Bardhan, P. and Mookherjee, D. (1999). Relative capture of local and central governments: An essay in the political economy of decentralization. Working paper, Department of Economics, Boston University.

Bardhan, P. and Mookherjee, D. (2000). Capture and governance at local and national levels. American Economic Review, 90(2):135-139.

Bardhan, P. and Mookherjee, D. (2006). Decentralization and local governance in developing countries. Cambridge: MIT press.

Bennet, A. (1999). Patient satisfaction in Bangkok: The impact of hospital ownership and patient payment status. International Journal for Quality in Health Care, 11(4):309-317.

Besley, T., Burges, R., and Prat, A. (2002). Mass media and political accountability. Working Paper LSE.

Blair, H. (2000). Participation and accountability at the periphery: Democratic local governance in six countries. World Development, 28(1):21-39. 


\section{Macrothink}

Journal of Public Administration and Governance

ISSN 2161-7104

2012, Vol. 2, No. 3

Blanchard, O. and Shleifer, A. (2000). Federalism with and without political centralization: China versus Russia. Working paper number 1889, Harvard Institute of Economic Research.

Booth, J. and Richard, P. (1998). Civil society, political capital, and democratization in Central America. The Journal of Politics, 3(60):780 - 800.

Bowles, S. and Gintis, H. (2002). Social capital and community governance. Economic Journal, 1(112):419 - 436.

Bratton, M. (2007). Are you being served? popular satisfaction with health and education services in Africa. Afrobarometer Working Paper, 4.

Brinkerhoff, D. and Goldsmith, A. (2003). How citizens participate in macroeconomic policy: International experience and implication for poverty reduction. World Development, 4(1):685-701.

Brown, K. and Coulter, P. (1983). Subjective and objective measures of police service delivery. Public Administration Review, 43(1):50-58.

Browne, M. and Cudeck, R. (1993). Alternative ways of assessing model. In Bollen, K. and Long, J., editors, Testing structural equation models. Newbury Park: Sage.

Browne, M. and Cudeck, R. (1996). Categorical variables in developmental research: Methods of analysis. In Eye, A. and Clogg, C., editors, Testing structural equation models. San Diego: Academic Press.

Conyers, D. (1983). Decentralization: The latest fashion in development administration. Public Administration and Development, 3(1):97-109.

Crook, R. and Manor, J. (1998). Democracy and decentralization in Southeast Asia and West Africa: Participation, accountability, and performance. Cambridge: Cambridge University press.

Deaton, A. (2001). Health, inequality, and economic development. Working papers 8318.

DeHoog, R., Lowery, D., and Lyons, W. (1990). Citizen satisfaction with local governance: A test of individual, jurisdictional, and city-specific explanations. Journal of Politics, 52(3):807-837.

Deichmann, U. and Lall, S. (2003). Are you satisfied? citizen feedback and delivery of urban services. Working papers number 3070, World Bank Policy Research.

deMello, L. and Barenstein, M. (2001). Fiscal decentralization and governance: A cross-country analysis. IMF Working Paper, 1(71):1-45.

Eckardt, S. (2008). Political accountability, fiscal conditions and local government performance: cross sectional evidence from Indonesia. Public Administration and 
Development, 28.

Erevelles, S. and Leavitt, C. (1992). A comparison of current models of consumer satisfaction/dissatisfaction. Journal of Consumer Satisfaction, Dissatisfaction, and Complaining Behavior, 5(1):104-114.

Fan, C., Lin, C., and Treisman, D. (2009). Political decentralization and corruption: Evidence from around the world. Journal of Public Economics, 93(1):14-34.

Fisman, R. and Gatti, R. (2002). Decentralization and corruption: Evidence across countries. Journal of Public Economics, 3(83):325-345.

Fox, J. and Aranda, J. (1996). Decentralization and rural development in Mexico: Community participation in Oaxaca's municipal funds program. La Jolla: Center for U.S-Mexican studies, Monograph series No. 42. San Diego: University of California.

Frey, B. and Stutzer, A. (2002). Happiness and economics: How the economy and institutions affect human wellbeing. New Jersey: Princeton University Press.

Fung, A. and Wright, E. (2003). Deepening democracy: Institutional innovations in empowered participatory governance. London: Verso.

Goldsmith, A. (1999). Slapping the grasping hand: Correlates of political corruption in emerging markets. American Journal of Economics and Sociology, 69(1):866-883.

Gong, T. (2006). Corruption and local governance: The double identity of Chinese local governments in market reform. The Pacific Review, 19(1):85-102.

Graham, C. (2009). Happiness around the world. Oxford: Oxford University Press.

Grindle, M. (2007). Going local: decentralization, democratization, and the promise of good governance. New Jersey: Princeton University press.

Grootaert, C. and Van-Bastelaer, T. (2002). The role of social capital in development: An empirical assessment. Cambridge: Cambridge University Press.

Heller, P. (2001). Moving the state: The politics of democratic decentralization in Kerala, South Africa, and Porto Alegre. Politics and Society, 29(1):131-163.

Hu, L. and Bentler, P. (1999). Cutoff criteria in fix indexes in covariance structure analysis: Conventional criteria versus new alternatives. Structural Equation Modelling, 1.

Kaiser, K. and Hofman, B. (2003). Decentralization, democratic transition, local governance in Indonesia. World Bank: Jakarta.

Kaiser, K., Pattinasarany, D., and Schulze, G. (2006). Decentralization, governance and public services in Indonesia. In Smoke, P., Gomez, E., and Peterson, G., editors, 
Decentralization in Asia and Latin America: Toward a comparative interdisciplinary perspective. Cheltenham: Edward Elgar.

Kruse, I., Pradhan, M., and Sparrow, R. (2009). Health spending and decentralization in Indonesia. Proceedings of the German Development Economics Conference No. 33.

Lane, R. (2000). The loss of happiness. New Heaven: Yale university Press.

Lanjouw, P., Pradhan, M., Saadah, F., Sayed, H., and Sparrow, R. (2001). Poverty, education and health in Indonesia: Who benefits from public spending? World Bank Research Working Paper 2739, 2.

Lessmann, C. and Markwardt, G. (2010). One size fits all? Decentralization, corruption, and the monitoring of bureaucrats. World Development, 38(4):631-646.

Litvack, J., Ahmad, J., and Bird, R. (1998). Rethinking decentralization in developing countries. Washington, D.C. : World Bank.

Maddala, G. (1999). On the use of panel data methods with cross-country. Annales deconomie et de statisque, 55 .

Malley, M. (2003). Local power and politics in Indonesia. In Aspinall, E. and Fearly, G., editors, Local power and politics in Indonesia decentralization and democratisation. Singapore: Institute for Southeast Asian Studies.

Manor, J. (1999). The political economy of democratic decentralization. Washington, D.C. : World Bank.

McGee, R. and Gaventa, J. (2011). Shifting power? assesing the impact of transparency and accountability initiatives. Institute Development Studies Working Paper, 1(383).

Muthen, L. and Muthen, B. (2010). Mplus users guide (six edition). Los Angeles: Muthen and Muthen.

Myburgh, E., Solanki, G., Smith, M., and Lalloo, R. (2005). Patient satisfaction with health care providers in South Africa: The influences of race and socioeconomic status. International Journal for Quality in Health Care, 17(6):473-477.

Nabeshima, K. (2003). Raising the quality of secondary education in East Asia. World Bank Policy Research Working Paper, (3140).

Oates, W. (1993). Fiscal decentralization and economic development. National Tax Journal, 46(1):237-243.

Oswald, A. and Wu, S. (2011). Well being across America. The review of economics and statistics, 93(4):1118 - 1134. 


\section{Macrothink}

Journal of Public Administration and Governance

ISSN 2161-7104

2012, Vol. 2, No. 3

Parks, R. (1984). Linking objective and subjective measures of performance. Public Administration Review, 44(2):118-127.

Pattinasarany, D. and Lewis, D. (2009). Determining citizen satisfaction with local public education in Indonesia: The significance of actual service quality and governance conditions. Growth and Change, 40(85):115-121.

Prud'homme, R. (1995). The dangers of decentralization. World Bank Research Observer, 2(10):201-220.

Putnam, R. (1993). Making Democracy Work. Civic Traditions in Modern Italy. New York: Princeton University press.

Rodriguez-Pose, A. and Gill, N. (2003). The global trend towards devolution and its implications. Environment and Planning C: Government and Policy, 21(3):333-351.

Rondinelli, D. (1982). The dilemma of development administration: Uncertainty and complexity in control oriented bureaucracies. World Politics, 35(1):43-72.

Rondinelli, D., McCoullough, J., and Johnson, R. (1989). Analyzing decentralization policies in developing countries: A political-economy framework. Development and Change, 20(1):5-27.

Shi_man, J. (2002). The construction of community participation: Village family planning groups and the Indonesian state. Social Science and Medicine, 1(54)::1199-1214.

Steiger, J. (1990). Structural model evaluation and modification. Multivariate Behavioural Research, 25.

Strauss, J., Beegle, K., Dwiyanto, A., Herawati, Y., Pattinasarany, D., Satriawan, E., Sikoki, B., Sukamdi, and Witoelar, F. (2004). Indonesian living standards: Before and after the financial crisis. Santa Monica: RAND Corporation.

Sullivan, J. (1992). Local government and community in Java: An urban case-study. New York : Oxford University Press.

Swindell, D. and Kelly, J. (2000). Linking citizen satisfaction data to performance measures: A preliminary evaluation. Public Performance and Management Review, 24(1):30 - 52.

Tabellini, P. (1992). The politics of 1992: Fiscal policy and European integration. Review of Economic Studies, 59(4):689 - 701.

Tiebout, C. (1956). A pure theory of local expenditures. Journal of Political Economy, 64(5):416 - 424.

Treisman, D. (2000). The causes of corruption: a cross-national study. Journal of Public Economics, 76(1):399-457. 


\section{Macrothink}

Journal of Public Administration and Governance ISSN 2161-7104 2012, Vol. 2, No. 3

Woolcock, M. (1998). Social capital and economic development: Toward a theoretical synthesis and policy framework. Theory and Society, 1(27):151-208.

World Bank (2003a). Decentralizing Indonesia. Jakarta: World Bank.

World Bank (2003b). Making services work for poor people. Washington D.C.: World Bank.

World Bank (2008). Decentralization in client countries: An evaluation of World Bank Support 1990 - 2007. Washington, DC: World Bank. 